
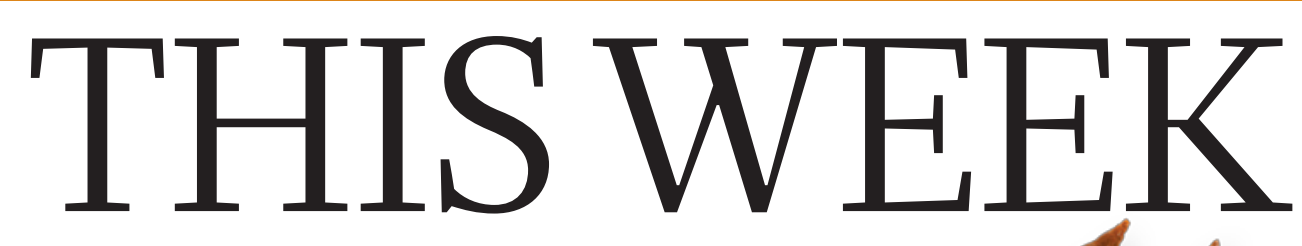

EDITORIALS

NEUROSCIENCE The ethical conundrum of brain stimulation $\mathbf{p . 8}$
WORLD VIEW Give judges and courts the facts on settled science $\mathbf{p . 9}$
DEVELOPMENT Protein

clue to the handedness of nature p.10

\title{
Unintended consequences
}

\section{After the introduction of a clumsily worded new rule, the UK government should move quickly to reassure scientists that they can continue to advise policymakers.}

$\mathrm{O}$ nly a fool ignores well informed advice. And only a very foolish government demands not to receive it in the first place.

But that is what the British government is in danger of doing. Last month the Cabinet Office - the ministry that supports the Prime Minister in running the government - introduced a new condition attached to government grants.

A new rule warns that money from any grant, either issued direct from departments or through third parties, cannot be used to "support activity intended to influence or attempt to influence Parliament, government or political parties ... or attempting to influence legislative or regulatory action".

Despite increasing concern from academics, the Department for Business, Innovation and Skills, responsible for billions of pounds of research funding, could not say as Nature went to press whether the rule would apply to science grants and university funding. The research councils and the Higher Education Funding Council for England - which actually parcel up the money for institutions and academics - are equally in the dark. All of which leaves scientists fearing that they are about to be muzzled.

This situation is not as shocking as in Canada, where a previous government deliberately set out to gag its researchers. Instead, the UK case seems to be more cock-up than conspiracy. No official seems to have thought through what it might mean to stop anyone who receives government money saying anything of substance to government. The Cabinet Office says that the clause was introduced to stop bodies that rely on government funds from lobbying government for more funding.

What could be lost if this clause is implemented fully is unclear. The specifics of how it will work have not been set out in great detail. But it could cover some of what government-funded scientists already do. A group of cross-party politicians in the House of Lords, for example, is conducting an inquiry into what impact the result of the United Kingdom's pending referendum, on whether to stay in or quit the European Union, would have on science. Among those giving evidence to the Lords are seven research institutions that are either government-owned or receive substantial government grants, including the Met Office weather agency, animal-health centre the Pirbright Institute in Surrey and the plant experts at the John Innes Centre in Norwich. Then there are nine universities or university centres, plus individual professors.

All the evidence culled from this wealth of expertise could be jeopardized by a heavy-handed implementation of this clause - for what is the point of evidence that has no influence? Even if these groups did still give evidence, some of it would have to be watered down or heavily qualified. Academic input has enlightened discussions of climate change, pollinator declines, biomedical ethics and many other issues of crucial importance to the future of the United Kingdom and the wider world.

The clause does not even limit itself to activity that tries to influence the United Kingdom; it merely forbids "attempting to influence legislative or regulatory action". Will some of the world's leading climate scientists be prevented from contributing to the Intergovernmental Panel on Climate Change's Summary for Policymakers because they are dependent on government money? Should British wildlife experts not give policy advice to foreign nations attempting

\section{"The UK case seems to be more cock-up than conspiracy."} to save biodiversity? Surely not, but this is one possible reading of the clause.

Scientists in the United Kingdom could be forgiven for feeling baffled by the development, given that the government-funded research councils have spent recent years promoting the 'impact agenda'. This encourages scientists to make sure that their work has reach outside their own academic disciplines, including influencing policy and legislation.

Officials have indicated that the problem can be fixed. Ministers have the power to remove the rule entirely from grants, or add in 'qualifications' that could permit some limited additional uses for the money.

All researchers supported by government - regardless of what organizational auspice they operate under - should be in no doubt that they have not only a right but a duty to speak out about the implications of their work. There must be a complete exemption of any research from this clause, not just for those who work in academia, but for those who work directly for government.

\section{Future present}

A young global-sustainability platform deserves time to find its feet.

$\mathrm{I}$ n pure science, as in art, little is urgent. Gravitational waves were discovered - a triumph for curiosity-driven science - thanks to physicists' patience and imaginative power. That they had waited decades is irrelevant. Alas, not all science has the luxury of timelessness.

Urgent science touches on issues that rank high on the social agenda. Theorists have classified fields such as climatology and global-change research as post-normal science, in which socio-economic stakes are high and decisions are pressing. That is the case with the agenda of Future Earth, an international sustainability-research platform set up in 2012 to tackle complex social challenges, from climate change to finance.

The scheme replaces a number of narrower programmes, including the international Geosphere-Biosphere and Human Dimensions programmes, which - to the regret of many - are now all closed. 